\title{
Occurrence of Phelypera griseofasciata and its parasitism in munguba in Seropédica, Rio de Janeiro
}

\section{Ocorrência de Phelypera griseofasciata e seu parasitismo em munguba em Seropédica, Rio de Janeiro}

\author{
Thiago Sampaio de Souza' (1D) (orcid.org/0000-0003-1604-5521) \\ Elen de Lima Aguiar-Menezes ${ }^{1}$ (1) (orcid.org/0000-0003-3634-0202) \\ André Luis Santos Resende' ${ }^{1}$ (D) (orcid.org/0000-0001-5808-2596) \\ Valmir Antonio Costa ${ }^{2}$ (D) (orcid.org/0000-0003-0122-3567) \\ Henrique Trevisan' (D) (orcid.org/0000-0003-0155-231X)
}

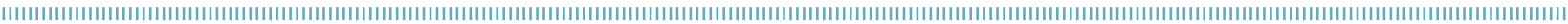

\begin{abstract}
Pachira aquatica (Malvaceae), known as munguba, is cultivated for afforestation of many Brazilian cities. In Seropédica campus of UFRRJ, it was observed the defoliation of one specimen of Pachira aquatica with presence of larvae, pre-pupae, and pupae of beetle of the subfamily Hyperinae, which were reared in laboratory until the emergence of the adults; these insects were identified as belonging to the species Phelypera griseofasciata Capiomont (Coleoptera: Curculionidae). These immature forms $(n=86)$ were again collected in this same specimen and reared in laboratory to verify the occurrence of parasitism. It was obtained 128 adults of Jaliscoa nudipennis Bouček (Hymenoptera: Pteromalidae), responsible for $44.2 \%$ of total parasitism. The sex ratio was 0.70 , so the highest number of offspring was of females. Intersexual and intrasexual dimorphisms were also observed in J. nudipennis regarding the shape of the head and characteristics of the wings. This study is the first record of both insect species associated with Pachira aquatica in the state of Rio de Janeiro, Brazil.
\end{abstract}

KEYWORDS: tritrophic relationship; defoliator beetle; Pteromalidae; Pachira aquatica.
RESUMO: Pachira aquatica (Malvaceae), conhecida como munguba, é cultivada para arborização de muitas cidades brasileiras. No campus de Seropédica da UFRRJ, observou-se o desfolhamento de um espécime de Pachira aquatica, com a presença de larvas, pré-pupas e pupas de besouro da subfamília Hyperinae, que foram criadas em laboratório até a emergência dos adultos; esses insetos foram identificados como pertencentes à espécie Phelypera griseofasciata Capiomont (Coleoptera: Curculionidae). Essas formas imaturas $(\mathrm{n}=86)$ foram novamente coletadas nesse mesmo espécime e criadas em laboratório para verificar a ocorrência de parasitismo. Foram obtidos 128 adultos de Jaliscoa nudipennis Bouček (Hymenoptera: Pteromalidae), responsáveis por $44,2 \%$ do parasitismo total. A razão sexual foi de 0,70 , portanto, o maior número de descendentes foi de fêmeas. Observaram-se ainda os dimorfismos inter e intrasexuais em J. nudipennis quanto ao formato da cabeça e às características das asas. Este estudo trata-se do primeiro registro de ambas as espécies de insetos associadas a Pachira aquatica no estado do Rio de Janeiro, Brasil.

PALAVRAS-CHAVE: relação tritrófica; besouro desfolhador; Pteromalidae; Pachira aquatica.

\footnotetext{
'Universidade Federal Rural do Rio de Janeiro - Seropédica (RJ), Brazil ${ }^{2}$ Instituto Biológico - Campinas (SP), Brazil

*Corresponding author: thiagosampaio.agro@gmail.com Received on: 10/20/2018. Accepted on: 01/24/2020
} 
In addition to the landscape aspect, urban afforestation plays a key role in providing shading for thermal comfort, improving air quality, sheltering wildlife, mitigating noise pollution, absorbing carbon from vehicles and from human activities in urban areas, among others, in order to improve human wellbeing (CEMIG, 2011; OLDFIELD et al., 2013).

Native tree species are preferentially selected at the time to plan urban afforestation in sustainable cities, since they can rapidly adapt to the environment and help preserving biodiversity (CEMIG, 2011; OLDFIELD et al., 2013). However, phytosanitary issues can emerge, mainly when trees do adapt to the ecosystem where they were planted in, a fact that can damage or even kill entire trees or parts of them, as well as cause severe accidents (CEMIG, 2011; BOBROWSKI, 2016). Thus, these issues are an important aspect to be taken into consideration to enable the conservation of trees used in urban afforestation processes.

Pachira aquatica (Malvaceae) is a tree species native to Southern Mexico, which is widely distributed in Northern South America, from the Amazon region to Maranhão state, where it is popularly known as munguba - it prevails in wetlands, mainly alongside rivers, streams, and igapós (LORENZI, 1992; PEIXOTO; ESCUDEIRO, 2002). However, Pachira aquatica can also grow on dry ground (LORENZI, 1992). French botanist and landscape architect A.F.M. Glaziou used this species for urban afforestation purposes in Brazil, in the second half of the 19th century. In the 1960s, landscape architect Roberto Burle Marx and botanist Luiz Emygdio de Mello Filho were responsible for introducing munguba in large wooded areas such as Parque do Flamengo and Quinta da Boa Vista in Rio de Janeiro City, RJ (PEIXOTO; ESCUDEIRO, 2002). Pachira aquatica specimens compose the landscaping in Seropédica campus at Federal Rural University of Rio de Janeiro (UFRRJ - Universidade Federal Rural do Rio de Janeiro).

The aims of the present study were:

- To identify P. aquatica leaf beetle used in the afforestation of the Integrated Pest Management Center Center (CIMP - Centro Integrado de Manejo de Pragas) at UFRRJ Seropédica campus.

- To investigate the incidence of parasitism in its immature forms and, in case of parasitism incidence.

- To identify beetle specimens and to determine their parasitism rates and sex ratio.

On September 20, 2016, there was partial defoliation, mainly in the top region, of a Pachira aquatica specimen planted in front of the Integrated Pest Management of the Entomology and Plant Pathology Department (DEnF Departamento de Entomologia e Fitopatologia) of the UFRRJ Institute of Biological and Health Sciences, Seropédica campus (2244'29” S, 4342'19” W, altitude of 36 m). Many Pachira aquatica leaves had their limb fully consumed, although their ribs remained intact. Eruciform-type beetle larvae belonging to subfamily Hyperinae were found feeding on leaves.
Pre-pupae and pupae were also identified; they were encased in silk yarns, which were tangled with a broad, yellow-brown, oblong cocoon-shaped weave, besides being typical of the aforementioned subfamily of beetles.

Tree branches whose leaves presented larvae, pre-pupae, and pupae were collected and taken to the CIMP laboratory, where they were kept under room temperature and humidity conditions $\left(24 \pm 1^{\circ} \mathrm{C} ; 65 \pm 10 \% \mathrm{RH}\right)$ to enable their full development - adult individuals were analyzed to identify the species causing defoliation. Collected branches were placed in glass vials containing moistened paper towels in order to keep leaf turgidity. In addition, they were placed in Bioquip ${ }^{\circledast}$ polyethylene cage (dimensions - $30 \times 30 \times 30 \mathrm{~cm} ; 1-\mathrm{mm}$ fine mesh) until the emergence of adult individuals, which were subjected to specific identification. Larvae fed on pieces of Pachira aquatica tops collected from the same specimen they were collected from - leaves were previously washed and dried with paper towels. Adult individuals were identified based on comparison to specimens deposited at Costa Lima Entomological Collection (CECL — Coleção Entomológica Costa Lima) of DEnF / UFRRJ - these individuals were added to the aforementioned collection (n. 12505).

Subsequently, 22 third and fourth instar leaf beetle larvae, 25 pre-pupae, and 39 pupae $(\mathrm{n}=86)$ were collected from the Pachira aquatica specimen with defoliation planted at CIMP to investigate parasitism incidence. The collected material was individually placed in $30 \mathrm{~mL}$ clear glass vials sealed with PVC film, which were then kept under room temperature and humidity conditions $\left(24 \pm 1^{\circ} \mathrm{C} ; 65 \pm 10 \% \mathrm{RH}\right)$. Larvae fed on pieces of new Pachira aquatica leaves, which were previously washed and dried with paper towels — leaves were replaced on a daily basis. Adult individuals belonging to family Pteromalidae (Hymenoptera) were collected and sent to the Central Experimental Center of the Biological Institute (CEIB - Centro Experimental Central do Instituto Biológico) in Campinas County, SP (Brazil) for specific identification. Specimens were deposited in the CEIB "Oscar Monte" Entomophagous Insect Collection (IB-CBE) (referred to as IB-CBE-2641 to IB-CBE-2647) and in the Costa Lima Entomological Collection (CECL) (n. 12506 and 12507).

The leaf beetle species was identified as Phelypera griseofasciata Capiomont, 1887 (Coleoptera: Curculionidae, Hyperinae). According to reports in Brazil, this species has been causing defoliation in Pachira insignis trees in Santo Antonio de Jesus County (BA) and in Pachira aquatica trees planted in the streets of Bonfim County (BA), whose specimens were found totally or partially defoliated by this insect (COSTA LIMA, 1956).

Of the 86 immature Phelypera griseofasciata forms, $44.2 \%$ were parasitized by endoparasitoids belonging to family Pteromalidae (Hymenoptera). Specimens were identified as belonging to species Jaliscoa nudipennis Bouček (Hymenoptera: Pteromalidae), based on BOUČEK; HEYDON (1997) and GIBSON (2013). 
Jaliscoa nudipennis is registered in several Neotropical countries such as Brazil, Cuba, Guatemala, Honduras, Mexico, and Venezuela (BOUČEK, 1993; GIBSON, 2013). VANIN et al. (2012) have reported the incidence of Jaliscoa nudipennis as Phelypera schuppeli pre-pupae parasitoid (Boheman, 1834) in Pachira aquatica in Dourados County (MS). GIBSON (2013) has reported the incidence of this parasitoid in Manaus (AM) and Encruzilhada counties (BA), although the host was not mentioned. Twelve Jaliscoa nudipennis specimens (seven females and five males) were deposited in the Entomological Collection of the Entomology Department at Luiz de Queiroz College of Agriculture/University of São Paulo (N. 6742); they were found in Phelypera griseofasciata individuals collected in Goiânia County (GO) in October 1982 (VAC, personal communication).

The present study was the first to record Phelypera griseofasciata incidence and its parasitism by Jaliscoa nudipennis in Rio de Janeiro State.

One hundred and eighty-two (182) adult Jaliscoa nudipennis individuals - 128 females and 54 males - were collected. Leaf beetles were parasitized by Jaliscoa nudipennis at all three developmental stages, although the prepupal stage recorded the highest parasitism rate (Table 1). The aforementioned parasitoid presented gregarious development; the number of emerged adult individuals changed depending on the developmental stage of the host. Four parasitoids (all female) emerged from the only parasitized larva. The number of adult Jaliscoa nudipennis individuals emerging from pre-pupae and pupae ranged from

Table 1. Number of adult individuals, parasitism rate, and sex ratio of Jaliscoa nudipennis individuals emerged in each developmental stage of host Phelypera griseofasciata in tree species Pachira aquatica.

\begin{tabular}{lccc} 
Developmental & \multicolumn{3}{c}{ Parasitoid } \\
\cline { 2 - 4 } stage & $\begin{array}{c}\text { No. of adult } \\
\text { individuals }\end{array}$ & $\begin{array}{c}\text { Parasitism } \\
\text { rate (\%) }\end{array}$ & Sex ratio' \\
\hline Larval & 4 & 4.5 & 1.00 \\
\hline Prepupal & 96 & 88.0 & 0.65 \\
\hline Pupal & 82 & 38.5 & 0.76 \\
\hline
\end{tabular}

'Sex ratio: ratio between the number of females and the total number of emerged parasitoids.
1 to 11 . The number of female Jaliscoa nudipennis offspring was always larger than that of males - total sex ratio was 0.70 . According to GODFRAY (1994), sex ratios tending to larger numbers of females are often observed in gregarious parasitoids whose mating most likely takes place between siblings or whose siblings compete to each other in order to mate.

There was also head shape dimorphism between male and female Jaliscoa nudipennis individuals, as reported by VANIN et al. (2012). However, male individuals have also shown intrasexual head shape dimorphism. The head of male Jaliscoa nudipennis individuals can be ellipsoid-elongated or ellipsoid-rounded, and their eyes are more separate from each other than those of female individuals - males' head width/height ratio ranged from 1.9 to $3.0 \mathrm{~mm}$ (Figs. 1A and $1 \mathrm{~B})$. Females' head width/height ratio reached $1.3 \mathrm{~mm}$; they presented round shaped- head, as reported by GIBSON (2013) (Fig. 1C). Of the 54 male Jaliscoa nudipennis individuals, 57.4 and $42.6 \%$ presented ellipsoid-rounded and ellipsoid-elongated head, respectively; the proportion between morphotypes changed depending on the developmental stage of the host - there was prevalence of the first morphotype (Table 2).

Jaliscoa nudipennis individuals also presented sexual dimorphism in wing features. Female individuals presented short setae mostly occupying the apical third of the forewings, after the stigmal vein (Fig. 2A), whereas male individuals presented larger setae in an area corresponding to the apical half (Fig. 2B). In addition, female individuals presented glabrous costal wing cell, as described by GIBSON (2013), whereas male individuals' forewings presented costal wing cell with three or four irregular rows of setae. The stigma in the forewings of male individuals was larger and darker than that of female individuals. Female individuals' hindwings were almost devoid of setae; the few ones were near the apex (Fig. 2C). On the other hand, male individuals presented larger setae occupying the entire width of the wing, from the basal end of the parastigma to the apex (Fig. 2D).

Dimorphism among males may be a determining factor in their competition with females, since males were to first to emerge. According to GODFRAY (1994), gregarious male parasitoids emerging from their hosts tend to mate with their sisters before they get dispersed; thus, mating and competition between siblings are highly likely to happen. However, it is necessary conducting further studies to test this hypothesis.
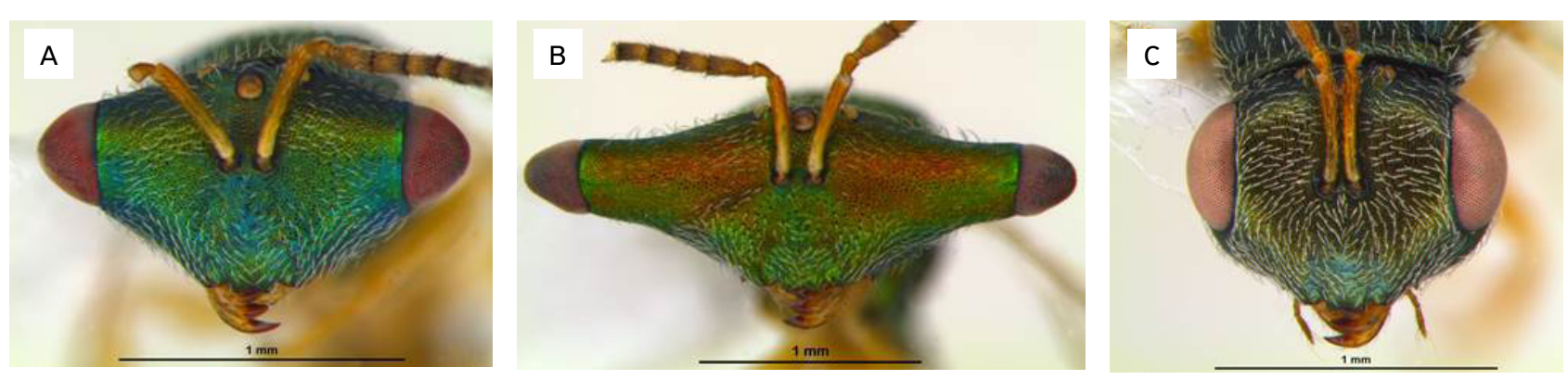

Figure 1. Frontal view of the head of male individuals: (A) ellipsoid-rounded head; $(B)$ ellipsoid-elongated head; and of female individuals (C) belonging to species Jaliscoa nudipennis (Photos: V.A. Costa). 
According to BOULTON et al. (2015), sexual dimorphisms in Hymenoptera parasitoids evolve based on several reasons, such as different ecological roles played by males and females, or on the competition for mates, whose tactics may comprise significant polymorphism in morphological or behavioral features.

According to MACEDO et al. (2013), sexual dimorphism in Eurytoma sp. (Hymenoptera: Eurytomidae) can influence sex ratio to the extent that intrasexual selection processes based on male size may have implications in resource allocation for male vs. female offspring production (sexual allocation). In light of the dimorphism found among male Jaliscoa nudipennis individuals, the current study has evaluated the sex ratio of each morphotype, in separate. The sex ratio recorded for the total number of males emerging from pre-pupae and pupae reached

Table 2. Total number of adult individuals, total percentage of male individuals, and head shape dimorphism rate in male Jaliscoa nudipennis individuals emerged in each developmental stage of host species Phelypera griseofasciata in tree species Pachira aquatica.

\begin{tabular}{lcccc} 
Developmental & $\begin{array}{c}\text { Emerged } \\
\text { stage }\end{array}$ & \multicolumn{3}{c}{ Male } \\
\cline { 5 - 6 }$(\mathbf{n})^{1}$ & $\begin{array}{c}\text { Emerged } \\
(\%)\end{array}$ & $\begin{array}{c}\text { ERH } \\
(\%)\end{array}$ & $\begin{array}{c}\text { EEH } \\
(\%)\end{array}$ \\
\hline Larval & 4 & - & - & - \\
\hline Prepupal & 96 & 35.4 & 60.0 & 40.0 \\
\hline Pupal & 82 & 24.4 & 55.9 & 44.1 \\
\hline
\end{tabular}

'total number of emerged parasitoids in each Phelypera griseofasciata developmental stage.

ERH: ellipsoid-rounded head; EEH: ellipsoid-elongated head.
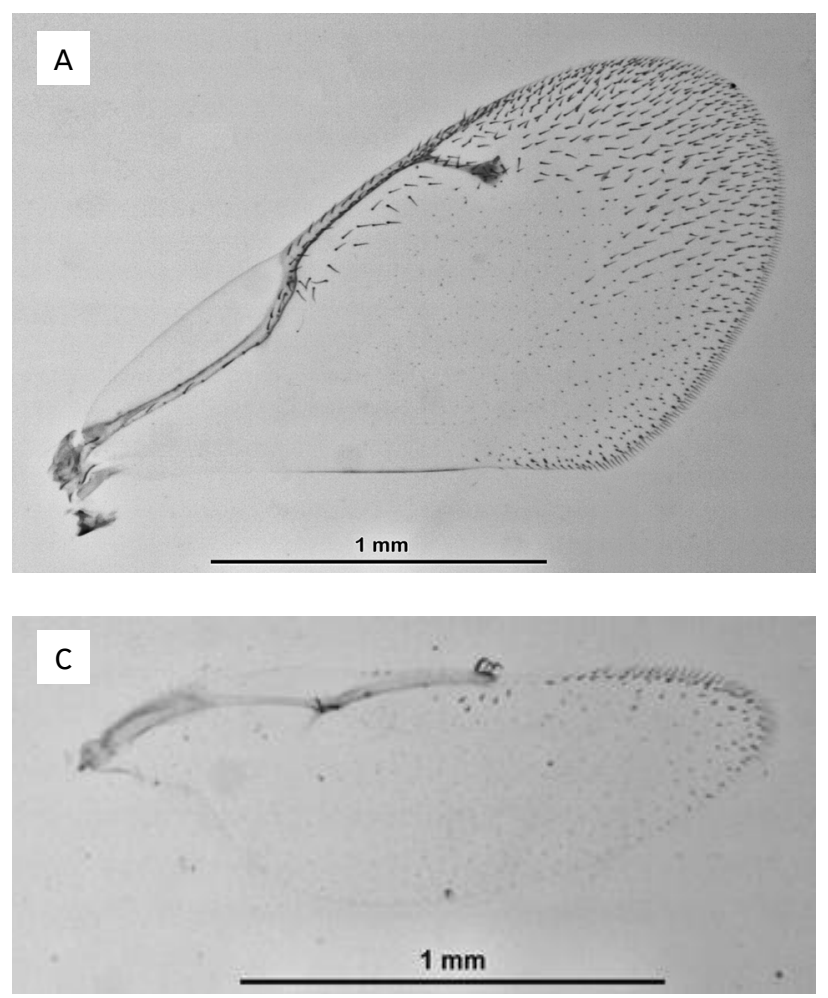

Figure 2. (A) Female, front wing; (B) male, front wing; (C) female, rear wing; (D) male, rear wing in Jaliscoa nudipennis individuals (Photos: V.A. Costa).

0.88 and 0.73 , respectively, when only individuals with ellipsoid-rounded head were taken into consideration. The sex ratio recorded for male individuals with ellipsoid-elongated head, who emerged from pre-pupae and pupae, reached 0.83 and 0.76 , respectively. Results in the current study have indicated that intrasexual dimorphism in males did not influence the trend of producing a larger number of female offspring.

According to ZHISHAN et al. (2003), in terms of biological pest control, sex ratio tending to larger numbers of female offspring is highly desirable, since females account for parasitism processes and, consequently, for reducing pest population density. Thus, Jaliscoa nudipennis emerges as a potential biological control agent. Importantly, there are no insecticides registered for Phelypera griseofasciata control purposes in Brazil.

Phelypera griseofasciata (Coleoptera: Curculionidae) larvae and adult individuals caused defoliation in tree species Pachira aquatica, which was used in the afforestation process implemented at UFRRJ's Seropédica campus. Phelypera griseofasciata larvae, pre-pupae, and pupae found in Pachira aquatica planted at UFRRJ's Seropédica campus were parasitized by Jaliscoa nudipennis (Hymenoptera: Pteromalidae).

The total rate of Phelypera griseofasciata parasitism recorded for Jaliscoa nudipennis in Pachira aquatica at UFRRJ's Seropédica campus was $44.2 \%$; this rate changed depending on hosts' developmental stage. Jaliscoa nudipennis recorded sex ratio equal to 0.70 ; this ratio changed depending on Phelypera griseofasciata developmental stage, when it was associated with Pachira aquatica at UFRRJ's Seropédica campus.
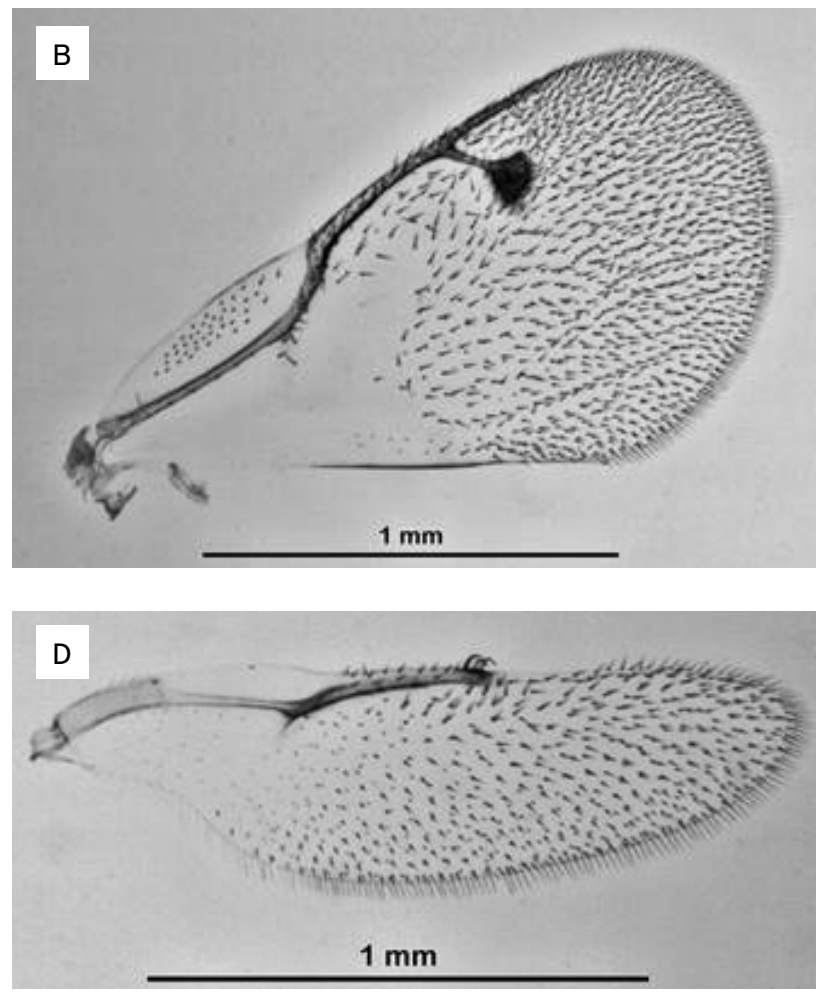
ACKNOWLEDGEMENTS: The scholarship grant to first author by the Coordenação de Aperfeiçoamento de Pessoal de Nível Superior - Brasil (CAPES) is gratefully acknowledged.

FUNDING: This study was funded by the National Science and Technology Institute for Hymenoptera Parasitoids in the Brazilian Southeastern Region (INCT Hympar/SE — Instituto Nacional de Ciência e Tecnologia dos Hymenoptera Parasitoides da Região Sudeste Brasileira) and the Conselho Nacional de Desenvolvimento Científico e Tecnológico (CNPq) (CNPq process n. 573802/2008-4).

CONFLICTS OF INTEREST: All authors declare that they have no conflict of interest.

ETHICAL APPROVAL: Not applicable.

AVAILABILITY OF DATA AND MATERIAL: The datasets generated and/or analyzed during the current study are available in the "Oscar Monte" Entomophagous Insect Collection (IB-CBE) and in the Costa Lima Entomological Collection (CECL), http:// www.biologico.sp.gov.br/page/colecoes/apresentacao and http://www.ufrrj.br/institutos/ib/ento/entocol.htm, respectively.

AUTHORS' CONTRIBUTIONS: Conceptualization: Souza, T.S.; Resende, A.L.S.; Trevisan, H. Writing - original draft: Souza, T.S.; Resende, A.L.S.; Trevisan, H. Writing - review \& editing: Aguiar-Menezes, E.L.; Costa, V.A.

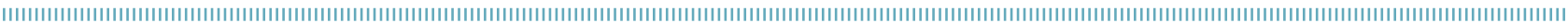
REFERENCES

BOUČEK, Z. New taxa of North American Pteromalidae and Tetracampidae (Hymenoptera), with notes. Journal of Natural History, London, v.27, n.6, p.1239-1313, 1993. https://doi. org/10.1080/00222939300770741

BOUČEK, Z; HEYDON, S.L. Pteromalidae. In: GIBSON, G.A.P.; HUBER, J.T.; WOOLLEY, J.B. (Eds). Annotated keys to the genera of Nearctic Chalcidoidea (Hymenoptera). Ottawa: NRC Research Press, 1997. p.541-692.

BOBROWSKI, R. Problemas e distinções entre métodos de avaliação da condição geral de árvores urbanas. Revista da Sociedade Brasileira de Arborização Urbana, Piracicaba, v.11, n.2, p.1-11, 2016. http://dx.doi.org/10.5380/revsbau.v 11 i2.63437

BOULTON, R.A.; COLLINS, L.A.; SHUKER, D.M. Beyond sex allocation: the role of mating systems in sexual selection in parasitoid wasps. Biological Reviews, Cambridge, v.90, n.2, p.599-627, 2015. http://dx.doi.org/10.1111/brv.12126

COMPANHIA ENERGÉTICA DE MINAS GERAIS (CEMIG). Manual de arborização. Belo Horizonte: Cemig, Fundação Biodiversidade, $2011.112 \mathrm{p}$.

COSTA LIMA, A. Insetos do Brasil, Coleópteros, 4. ${ }^{a}$ parte e última parte. Rio de Janeiro: Escola Nacional de Agronomia, 1956. 373p.

GIBSON, G.A.P. Revision of the species of Jaliscoa Bouček within a review of the identity, relationships and membership of Jaliscoa, Catolaccus Thomson, Eurydinoteloides Girault, Lyrcus Walker and Trimeromicrus Gahan (Hymenoptera: Pteromalidae). Zootaxa, Auckland, v.3612, p.1-85, 2013. http://dx.doi.org/10.11646/ zootaxa.3612.1.1
GODFRAY, HCJ. Parasitoids: behavioral and evolutionary ecology. Princeton: Princeton University Press, 1994. 473p.

LORENZI, H. Árvores brasileiras: manual de identificação e cultivo de plantas arbóreas nativas do Brasil. Nova Odessa: Plantarum, 1992. 368p.

MACEDO, M.V.; MONTEIRO, R.F.; SILVEIRA, M.P.; MAYHEW, P.J. Male-male competition for mates, sexual size dimorphism and sex ratio in a natural population of a solitary parasitoid. Behavioural Processes, Netherlands, v.100, p.1-8, 2013. https:// doi.org/10.1016/j.beproc.2013.07.003

OLDFIELD, E.E.; WARREN, R.J.; FELSON, A.J.; BRADFORD, M.A. FORUM: Challenges and future directions in urban afforestation. Journal of Applied Ecology, London, v.50, n.5, p.1169-1177, 2013. https://doi.org/10.1111/1365-2664.12124

PEIXOTO, A.L.; ESCUDEIRO, A. Pachira aquatica (Bombacaceae) na obra "história dos animais e árvores do Maranhão" de Frei Cristóvão de Lisboa. Rodriguésia, Rio de Janeiro, v.53, n.82, p.123-130, 2002. https://doi.org/10.1590/2175-78602002538205

VANIN, S.A.; BENA, D.C.; ALBERTONI, F.F. Description of immature stages of Phelypera schuppeli (Boheman, 1834) with comments on natural history (Coleoptera: Curculionidae, Hyperinae). Zootaxa, Auckland, v.3423,p.45-60, 2012.https://doi.org/10.1 1646/zootaxa.3423.1.4

ZHISHAN, W.U.; HOPPER, K.R.; ODE, P.J.; FUESTER, R.W.; JIAHUA, C.; HEIMPEL, G.E. Complementary sex determination in Hymenopteran parasitoids and its implications for biological control. Acta Entomologica Sinica, Beijing, v.10, n.2, p.81-93, 2003. https://doi.org/10.1111/j.1744-7917.2003.tb00369.x 